Editorial

\title{
The right to food and health for patients: challenges of a world in crisis
}

\section{Editorial}

Adequate nutrition and health care should be guaranteed to all people independent of where they live or who they are. It is easy to say, but very difficult to accomplish. In the modern world as changes in people's life are introduced, different challenges arise. One of them is to feed the planet's population, adequately, sufficiently and with dignity.

Many of the modern health concerns are associated to the way people are feeding themselves or fed by others, such is the case of children, which must be fed by their parent or caregivers. Children, then can be well fed or not being fed well enough. Therefore, chronic diseases related to nutrition are on the table for discussion because among other issues, prevention can be achieved by modifiable factors at low cost: a good and nutritious diet and physical activity as major components of a good life style. ${ }^{1}$

On the other hand, particularly in the developing world, achieving a good nutrition status and follow a good life style can be challenging. Many progress have been made toward achieving a better access to food, reducing undernutrition and better intake of micronutrients, yet globally, there are about 795 million people experiencing hunger. ${ }^{2}$

The articles number eleven and twelve of the international covenant of economic, social and cultural rights state that it should be recognized the right of every human being to an adequate life standard for him/herself and their families, including food, dress and housing and to continuing improving their life conditions; as well as the right of every individual to the fulfillment of the best and highest possible standard of physical and mental health. ${ }^{3}$

From this perspective the fact many people are showing a poor quality dietary pattern, and key nutrients inadequacy, ${ }^{3}$ should be an important statement to work toward a better health for chronic patients for whom the access to a quality and healthy diet is important. For type 2 diabetic patients not only it is important to eat food, it should be quality foods that meet their requirements as well as allow a better prognosis of the disease.

An effort for guaranteeing the right to health and food to patients with chronic diseases is yet to be improved, since the majority of
Volume 4 Issue 5 - 2017

\author{
Marianella Herrera-Cuenca \\ Chair of the Department Development and Health, Central \\ University of Venezuela (UCV), SA
}

Correspondence: Marianella Herrera-Cuenca, Associate Professor and Researcher Center for Development Studies (CENDES), Chair of the Department Development and Health, Central University of Venezuela (UCV), SA, Email manyma@gmail.com

Received: August 02, 2017 | Published: August 16, 2017

works have been made toward feeding the population no matter what, in consequence, the time historic period of dense in calories/ low cost foods should be reviewed because not only it is important to satiate hunger, but achieve a healthy and adequate nutrition status that allow people to live in the best possible conditions according to the international covenant treaties. ${ }^{3}$

\section{Acknowledgements}

None.

\section{Conflict of interest}

Author declares that there is no conflict of interest.

\section{References}

1. Standards of Medical Care in Diabetes 2016. American Diabetes Association (ADA). Diabetes Care. 2016;39(Suppl 1):S1-S2.

2. Beal T, Massiot E, Arsenault JE, et al. Global trends in dietary micronutrients supplies and estimated prevalence of inadequate intakes. PLoS One. 2017;12(4):e0175554.

3. Naciones Unidas. Oficina del Alto Comisionado de las Naciones Unidas para los Derechos Humanos. Los Derechos Económicos, Sociales y Culturales. Manual para las Instituciones Nacionales de Derechos Humanos. Serie de Capacitacion Profesional N 12. Nueva York y Ginebra; 2004. 